\title{
Evaluation of maternal mortality and their factors in GMCH, Aurangabad, India
}

\section{Ganesh Balasaheb Bharaswadkar*, Murlidhar L. Kurtadikar}

Department of Obstetrics and Gynecology, Government Medical College and Hospital, Aurangabad, Maharashtra, India

Received: 08 January 2017

Accepted: 28 January 2018

*Correspondence:

Dr. Ganesh Balasaheb Bharaswadkar,

E-mail: ganeshbharaswadkar@rediffmail.com

Copyright: (c) the author(s), publisher and licensee Medip Academy. This is an open-access article distributed under the terms of the Creative Commons Attribution Non-Commercial License, which permits unrestricted non-commercial use, distribution, and reproduction in any medium, provided the original work is properly cited.

\section{ABSTRACT}

Background: Analysing the factors related to maternal mortality is very important as they reflect the socioeconomic status and health care facility availabilities of the country. This study is aimed to analyse the epidemiological aspects and different causes of maternal death and evaluation of preventable factors and unavoidable factors if any causing maternal death.

Methods: The retrospective study was carried out at GMCH, Aurangabad during the period from February 2002 to January 2004. All the data related to epidemiological factors and causes of maternal mortality was recorded and analyzed.

Results: There were 33 maternal deaths during the study period. The mean maternal mortality rate was 211 per $1,00,000$ total births. Maximum maternal deaths were reported at the age group of 26-30 years (36.1\%), in primiparous women $(46.8 \%)$ and from rural areas (78.38\%). Most of the deaths $(37.5 \%)$ were reported within first 24 hours of hospital admission at postpartum stage (87.5\%). $84.37 \%$ of maternal deaths were due to direct causes. And toxemia of pregnancy (39.5\%) was major direct cause. Anaemia and infective hepatitis constitutes for $9.3 \%$ each for the indirect causes maternal death.

Conclusion: Most maternal deaths can be preventable by multidisciplinary approaches involving mass community education, improving sanitation, early referrals to tertiary care centres and by providing health care facilities in rural areas.

Keywords: Direct and indirect causes, Infective hepatitis, Maternal mortality, Toxemia

\section{INTRODUCTION}

Maternal mortality in developing countries acts as one of the health indicator and reflects the efficiency of health care of the nation. ${ }^{1,2}$ This can be expressed in terms of maternal mortality rate (MMR). It is defined as maternal death rate per 1,00,000 live births. ${ }^{3}$ It not only judges the health care facilities provided by the country but also reflects the education and socioeconomic status of the people. In India the MMR rate is 174 per 100, 000 live births, which is far above the desired goal of 100 per 1 ,
00,000 live births as per the objectives of Millennium Development Goals (MDG).,

Most of the data related to maternal mortality is attained through hospital data and community-based reports, which are located mostly in urban areas, but most of the maternal mortality is seen from rural areas. This present study was done to analyse the epidemiological aspects and different causes of maternal death and evaluation of preventable factors and unavoidable factors if any causing maternal death. 
GMCH Aurangabad being a tertiary health centre with large drain area covering suburban as well as rural areas, so the study was conducted to get the idea of quality of maternity services existing in this region.

\section{METHODS}

The present study was retrospective study carried out at GMCH, Aurangabad during the period from February 2002 to January 2004. During this period data regarding maternal mortality was collected from the maternal mortality register after obtaining permission from institutional ethics committee. All the data regarding whether the woman was registered/unregistered, transferred/arrival from home, rural/urban details about age, parity and causes of death were critically analysed with a view to find out the factors associated and contributing to maternal deaths. All the maternal deaths due to complications during pregnancy are included in this study.

Maternal mortality rate is expressed as number of maternal deaths per 1,00,000 total births. Wherever there was more than one contributory cause, main cause of death was recorded. Attempts are made to identify avoidable factors. In this study, main emphasis way given to direct obstetric death along with indirect cause of death and at what level that was preventable.

\section{RESULTS}

During this study period there were a total of 15,122 births and 33 maternal deaths. The mean maternal mortality rate was 211 per $1,00,000$ total births.

Table 1 presents the epidemiological characteristics of maternal death. Maximum numbers of maternal deaths were reported at the age group of 26-30 years (36.1\%). Most of the deaths were reported in primiparous women (46.8\%). Maximum maternal deaths were reported from rural areas $(78.38 \%)$. Of total cases 4,108 cases were registered and 11,014 cases were unregistered. Among them, 7 (18.91\%) cases from booked and $2(81.09 \%)$ from un-booked cases have died. Maximum deaths $(50 \%)$ occurred in the third trimester of pregnancy. Most of the deaths $(37.5 \%)$ were reported within first 24 hours of hospital admission. Majority of the maternal deaths were reported at postpartum stage $(87.5 \%)$.

During this study period, $84.37 \%$ of maternal deaths were due to direct causes. The toxemia of pregnancy $(39.5 \%)$ was major direct causes of maternal death. Of which 12 deaths were due to eclampsia in antepartum period and 1 death due to eclampsia in postpartum period.

In this study, $15.63 \%$ of maternal deaths were due to indirect causes. Anaemia and infective hepatitis constitutes of $9.3 \%$ each for the indirect causes maternal death.
Table 1: Epidemiological characteristics of maternal deaths $(n=33)$.

\begin{tabular}{|c|c|c|}
\hline $\begin{array}{l}\text { Patient } \\
\text { characteristics }\end{array}$ & $\begin{array}{l}\text { No. of maternal } \\
\text { deaths }(n=33)\end{array}$ & Percentage \\
\hline \multicolumn{3}{|l|}{ Age (in years) } \\
\hline $15-20$ & 3 & 9.1 \\
\hline $21-25$ & 10 & 30.3 \\
\hline $26-30$ & 13 & 39.4 \\
\hline $31-35$ & 6 & 18.2 \\
\hline$>35$ & 1 & 3.1 \\
\hline \multicolumn{3}{|l|}{ Parity } \\
\hline 1 & 15 & 45.4 \\
\hline 2 & 10 & 30.3 \\
\hline 3 & 5 & 15.1 \\
\hline 4 & 2 & 6.1 \\
\hline 5 & 1 & 3.1 \\
\hline \multicolumn{3}{|l|}{ Residence } \\
\hline Rural areas $(n=8608)$ & 25 & 75.8 \\
\hline $\begin{array}{l}\text { Urban areas } \\
(\mathrm{n}=6,514)\end{array}$ & 8 & 24.2 \\
\hline \multicolumn{3}{|l|}{ Antenatal care } \\
\hline Registered (n=4108) & 7 & 18.9 \\
\hline $\begin{array}{l}\text { Unregistered } \\
(\mathrm{n}=11014)\end{array}$ & 2 & 81.1 \\
\hline \multicolumn{3}{|c|}{ Admission to death interval } \\
\hline 0-6 hours & 12 & 36.3 \\
\hline 7-24 hours & 9 & 27.2 \\
\hline $1-3$ days & 8 & 24.2 \\
\hline 4.7 days & 2 & 6.1 \\
\hline $8-15$ days & 2 & 6.1 \\
\hline$>16$ days & 0 & 0 \\
\hline \multicolumn{3}{|c|}{$\begin{array}{l}\text { Incidence of death in relation to status of pregnancy } \\
\text { and labor }\end{array}$} \\
\hline Abortions & 0 & 0 \\
\hline Antepartum & 3 & 9.1 \\
\hline Intrapartum & 2 & 6.1 \\
\hline Postpartum & 28 & 84.8 \\
\hline
\end{tabular}

Table 2: Direct causes of maternal death.

\begin{tabular}{|c|c|c|}
\hline Direct causes & $\begin{array}{l}\text { Number of } \\
\text { maternal } \\
\text { deaths }(n=27)\end{array}$ & $\begin{array}{l}\text { Percentage } \\
(\%)\end{array}$ \\
\hline \multicolumn{3}{|l|}{ Sepsis $(n=4)$} \\
\hline Puerperal sepsis & 3 & 11.1 \\
\hline Antepartum sepsis & 1 & 3.7 \\
\hline \multicolumn{3}{|l|}{ Hemorrhage $(n=8)$} \\
\hline Placenta previa & 2 & 7.4 \\
\hline Abruptio placentae & 2 & 7.4 \\
\hline $\begin{array}{l}\text { Atonic postpartum } \\
\text { hemorrhage }\end{array}$ & 4 & 14.8 \\
\hline \multicolumn{3}{|l|}{ Toxemia $(n=13)$} \\
\hline Antepartum eclampsia & 12 & 44.4 \\
\hline Postpartum eclampsia & 1 & 3.7 \\
\hline \multicolumn{3}{|c|}{ Obstructed trauma $(n=2)$} \\
\hline Rupture uterus & 1 & 3.7 \\
\hline Inversion of uterus & 1 & 3.7 \\
\hline
\end{tabular}


Table 3: Indirect causes of maternal death.

\begin{tabular}{|lll|}
\hline $\begin{array}{l}\text { Indirect } \\
\text { causes }\end{array}$ & $\begin{array}{l}\text { Number of maternal } \\
\text { deaths }(\mathrm{n}=6)\end{array}$ & $\begin{array}{l}\text { Percentage } \\
(\%)\end{array}$ \\
\hline $\begin{array}{l}\text { Infective } \\
\text { hepatitis }\end{array}$ & 3 & 50 \\
\hline Anaemia & 3 & 50 \\
\hline
\end{tabular}

\section{DISCUSSION}

The objective of obstetrics is that every pregnancy should culminate in a healthy mother and healthy baby. Most of developed countries have achieved a major success in reducing their maternal mortality. The current maternal mortality rate in India is 174 per 100, 000 live births, which is a significant decline from the 215 that was reported in $2010 .^{4}$

In the present study, the mean mortality rate was 211 per $1,00,000$ total births. In a study by Murthy et al the mean mortality rate was $302.23 / 100000$ births for 120 deaths. $^{6}$

Maximum number of mortality deaths was reported in the age group of 26-30 years. More number of maternal deaths was noticed in women from rural areas (75.58\%). These findings were similar to the studies of Murthy et al and Khandale et al. ${ }^{6,7}$ The reason behind this might be due to the early marriages, poor sanitation and poor transport facilities in rural areas.

Proper antenatal care reduces the incidence of complications both in ante and intrantal period. Antenatal care helps in detection of toxaemia, anaemia and other medical disorders like cardiac disease, diabetes mellitus, chronic nephritis etc. which can alter the course of pregnancy. In present series $81 \%$ death were from unregistered cases. Similar observations were also made by Jain et al and Jadhav et al. ${ }^{8,9}$

In our study, maximum deaths (84.8\%) occurred in postpartum period. Similar results were reported by Das et al and Dogra et al. ${ }^{10,11}$ The causes behind postpartum death were mostly the pathology which started in antepartum period may get exacerbated following the labour.

In the present study, majority of the women $(36.3 \%)$ died within 6 hours of admission followed by 7-24 hours of admission $(27.2 \%)$ to the hospital. Similar reports were also given by Das et al and Pundare et al. ${ }^{10,12}$ These findings suggest that majority of the patients reaching the tertiary care quite late. Establishment of both basic and comprehensive emergency obstetrics care even at primary health centre level and first referral unit could possibly minimizes the maternal deaths.

In our study, direct causes of maternal mortality contribute to toxemia/pre-eclampsia $(48.1 \%)$ as the most common cause followed by haemorrhage $(29.6 \%)$, sepsis $(14.8 \%)$ and obstructed trauma (7.4\%). These observations were in accordance with the findings of El Daba et $\mathrm{al}^{13}$ High incidence of eclampsiawas due to delayed referral mostly after 12 hours of the incidence.

In this study, indirect causes of maternal death were due to infective hepatitis and anaemia. In a study by Murthy et al the rate of incidence of jaundice and anemia was found to be $9.16 \%$ and $10 \%$ respectively. ${ }^{6}$ In another study by Das et al on 47 cases of maternal death due to indirect cause, the main reason noticed was heart disease $(6.64 \%){ }^{10}$

Maternal deaths can be minimized in rural areas by improving sanitation facilities, education, and health care facilities by ensuring 24-hour availability of basic drugs like tablet misoprostol and magnesium sulphate injection to treat postpartum haemorrhage and eclampsia as these are still major reasons for maternal deaths rural areas. Early detection of high risk pregnancy and rereferring them to near tertiary care hospitals and avoiding deliveries at home can minimize the deaths related to pregnancies.

\section{CONCLUSION}

Even today the mean mortality rate was higher in patients from rural areas, unbooked and in first delivery cases. Toxemia and hemorrhage constitutes the major causes of death. Hence improvement in primary health care facilities, developing tertiary care centers and implementation of NHRM programmes efficiently in rural areas can minimize the number of maternal deaths.

Funding: No funding sources Conflict of interest: None declared

Ethical approval: The study was approved by the Institutional Ethics Committee

\section{REFERENCES}

1. Panting-Kemp A, Geller SE, Nguyen T, Simonson L, Nuwayhid B, Castro L. Maternal deaths in an urban perinatal network, 1992-1998. Am J Obstet Gynecol. 2000;183:1207-12.

2. Hawkins JL, Birnbach DJ. Maternal mortality in the United States: where are we going and how will we get there? Anesth Analg. 2001;93:1-3.

3. Reproductive Health Indicators: Guidelines for their generation, interpretation and analysis for global monitoring. WHO, 2006.

4. India's maternal mortality rate on a decline. Available

http://www.hindustantimes.com/health/india-smaternal-mortality-rate-on-a-decline/story-

ZcnBG0kidtvPEkRnKNIOII.html. Accessed $27^{\text {th }}$ May 2017.

5. Trends in maternal mortality: 1990-2010, estimates developed by WHO, UNICEF, UNFPA and the World Bank. 2012. Available at 
http//www.unfpa.org/public/home/publications/pid/1 0728.

6. Murthy BK, Murthy MB, Prabhu PM. Maternal mortality in a tertiary care hospital: a 10-year review. Int J Prev Med. 2013;4(1):105-9.

7. Khandale SN, Kedar K. Analysis of maternal mortality: a retrospective study at tertiary care centre. Int J Reprod Contracept Obstet Gynecol. 2017;6:1610-3.

8. Jain M, Maharahaje S. Maternal mortality: a retrospective analysis of ten years in a tertiary hospital. Indian J Prev Soc Med. 2003;34:103-11.

9. Jadhav AJ, Rote PG. Maternal mortality-changing trends. J Obstet Gynaecol India. 2007;57:398-400.

10. Das R, Biswas S, Mukherjee A. Maternal mortality at a teaching hospital of rural India: a retrospective study. Int J Biomed Advan Res. 2014;5(2):114-6.
11. Dogra P, Gupta KB. A study of maternal mortality at a tertiary institute. Obs Gynae Today. 2009;115:5860.

12. Purandare N, Singh A, Upadhyae S, Saraogi RM. Maternal Mortality at a referral centre: a five-year study. J Obstet Gynaecol India. 2007;57:248-50.

13. El Daba AA, Amr YM, Marouf HM, Mostafa M. Retrospective study of maternal mortality in a tertiary hospital in Egypt. Anesth Essays Res. 2010;4(1):29-32.

Cite this article as: Bharaswadkar GB, Kurtadikar ML. Evaluation of maternal mortality and their factors in GMCH, Aurangabad, India. Int J Reprod Contracept Obstet Gynecol 2018;7:879-82. 